\title{
Mammal inventories in Seasonal Neotropical Forests: traditional approaches still compensate drawbacks of modern technologies
}

\author{
William D. Carvalho 1,2,3, Luís M. Rosalino ${ }^{3,4}$, Cristina H. Adania ${ }^{2}$ \& Carlos E. L. Esbérard
}

\author{
1. Laboratório de Diversidade de Morcegos, Instituto de Biologia Universidade Federal Rural do Rio de Janeiro - UFRRJ, BR 465, Km 7. Caixa Postal 74507، \\ 23890-000, Seropédica, RJ, Brazil. (wilruoca@hotmail.com, cesberard@superig.com.br) \\ 2. Associação Mata Ciliar, Av. Emílio Antonon, 1000, 13212-010, Jundiaí, SP, Brazil. (cristina.adania@mataciliar.org.br) \\ 3. Universidade de Lisboa, Centre for Ecology, Evolution and Environmental Changes (Ce3C), Faculdade de Ciências de Lisboa, Ed. C2, Campo Grande, \\ 1749-016 Lisboa, Portugal. \\ 4. CESAM \& Departamento de Biologia, Universidade de Aveiro, 3810-193 Aveiro, Portugal. (Imrosalino@ua.pt)
}

Received 31 May 2015

Accepted 17 February 2016

DOI: 10.1590/1678-4766e2016005

\begin{abstract}
Variation in body size, behavior, feeding habits and habitat use patterns in medium- and large-sized mammals influence the adequacy of sampling methods to register presence and abundance. Moreover, even if methods are similarly adequate, different methodologies result in distinct costefficiency relationships (i.e. some may have reduced costs, be less time-consuming and/or require less-skilled technicians). Focusing on three different sampling methods commonly used to monitor medium and large mammals in seasonal tropical forests, we compared the species richness detected by each method and quantified their cost-efficiencies: (1) camera traps; (2) line transects for direct observations of animals; and (3) line transects seeking tracks/ footprints. We simultaneously monitored medium and large mammals along five trails between July and August 2009 and January and February 2010, in the Serra do Japi Biological Reserve, São Paulo, Brazil. Data from two distinct seasons demonstrated that significantly higher species richness was achieved by using signs of presence and direct observations detected in transects. Camera traps recorded the fewest species, but represented the lowest cost per species. Direct observations and searches for tracks/footprints required a greater number of field technicians (with more skill and experience) to record the focal species and therefore have a higher cost, but allowed twice as many species to be recorded compared to camera traps. The choice of sampling methodology depends on the study objective, mammal species targeted and/or amount of resources available. We advocate use of camera traps for long-term studies and in conjunction with the other two methods to improve identification accuracy, allow individual identification and permit more accurate abundance estimates.
\end{abstract}

KEYWORDS. Camera trap, direct observations, mammals, abundance estimates, animal tracks.

RESUMO. Inventário de mamíferos em Floresta Neotropical Sazonal: abordagens tradicionais ainda compensam as desvantagens de tecnologias modernas. A variação no tamanho do corpo, comportamento, hábitos alimentares e padrões de uso de habitat em mamíferos de médio e grande porte influenciam a adequação de métodos de amostragem para o registro da presença e abundância. Além disso, mesmo se os métodos são igualmente adequados, diferentes metodologias resultam em distintas relações de custo-eficiência (ou seja, alguns métodos podem ter custos reduzidos, ser menos demorados e/ou exigir técnicos menos qualificados). Concentrando-se em três diferentes métodos comumente usados para monitorar mamíferos de médio e grande porte em florestas tropicais sazonais, comparamos a riqueza de espécies detectada por cada método e quantificamos seu custo-eficiência: (1) armadilhas fotográficas; (2) observações diretas de animais em transectos; e (3) busca por rastros/pegadas em transectos. Nós monitoramos simultaneamente grandes e médios mamíferos ao longo de cinco trilhas entre julho e agosto de 2009 e janeiro e fevereiro de 2010, na Reserva Biológica Serra do Japi, São Paulo, Brasil. Os dados das duas estações distintas demonstraram que, significativamente, uma maior riqueza de espécies foi alcançada através de procura por sinais e observações diretas em transectos. Armadilhas fotográficas registraram menor número de espécies, mas apresentaram um menor custo por espécie. Observações diretas e procura por rastros/pegadas requerem maior número de técnicos de campo (com maior habilidade e experiência) para registrar as espécies focais e, portanto, tiveram um custo mais elevado, mas permitiram que o dobro de espécies fosse gravado em comparação com armadilhas fotográficas. A escolha da metodologia de amostragem depende do objetivo do estudo, das espécies de mamíferos alvo e/ou da quantidade de recursos disponíveis. Nós defendemos o uso de armadilhas fotográficas para estudos de longo prazo e em conjunto com os outros dois métodos para melhorar a precisão na identificação, permitir a identificação individual e permitir estimativas de abundância mais precisas.

PALAVRAS-CHAVE. Armadilhas fotográficas, estimativa da abundância, mamíferos, observações diretas, rastros de animais.

Terrestrial mammals are a highly variable taxon in terms of body size, life history, behavior and habitat preferences so accurate mammal inventories require the use of multiple census methods, since specific techniques are required to register the presence of different mammalian taxa (e.g., cursorial species can be detected by their signs of 
presence while arboreal ones will be more easily identified by direct observations). Among the techniques developed for sampling and monitoring mammals, nowadays there is a tendency to apply non-invasive methods that avoid the need for animal handling and avoid directly perturbing them (LONG et al., 2008). The use of camera traps, systematic surveys for detection of signs of presence (e.g., footprints, tracks, scats) and direct observations of animals (e.g., EISENBERG \& THORIngton, 1973; EMmons et al., 1989; Silveira et al., 2003; SRBEK-ARAúJo \& ChIARELLO, 2005; LyRA-JorgE et al., 2008a; Ribeiro \& MELo, 2013) are among the most common non-invasive approaches to study mammals, especially for medium- and large-sized species (SRBEKARAúJo \& Chiarello, 2005; Negrão \& VAladARES-PÁDUA, 2006; TOBLER et al., 2008). Due to their greater usage, many studies have detailed the efficiencies of these approaches, testing different protocols to assess best use practices and field applicability (e.g., Silveira et al., 2003; Ribeiro \& Melo, 2013; Srbek-Araújo \& Chiarello, 2013).

Direct observations are mainly used to confirm species occurrence and to study the behavior of primates (PERES, 1999) or to survey large mammals (RUDRAN et al., 1996), but is also frequently employed as a complementary method to other mammalian survey techniques (e.g., CARVALHO et al., 2013). Detection of signs of presence is also a commonly used method, although it implies a high degree of expertise in identifying footprints and scats. This latter approach is often less accurate than other methods due to considerable bias associated with huge variation in the shape, color or scent of scats between individuals (see MontERroso et al., 2012). Although also influenced by weather conditions and/ or soil characteristics (CHAME, 2003), detection of tracks and footprints can be more accurate and can be optimized by using sand plots; a method also widely used for sampling and occasional recording of mammals (Scoss et al., 2004; Negrão \& Valadares-PÁdua, 2006; Carvalho et al., 2013), especially when soil conditions are not appropriate for footprint impressions. Sand plots can be used to detect cursorial species and can be implemented alone or as a complementary method in different sampling designs (Scoss et al., 2004; ESPARTOSA et al., 2011).

Camera-traps are mostly used for sampling medium and large mammals (e.g., AlvEs \& ANDRIOLO, 2005; LYRAJoRge et al., 2008a; Delciellos et al., 2012; CARVAlHo et al., 2013), to assess mammalian density if species characteristics allow individual identification (e.g., pelage patterns; MAFFEI et al., 2011), or for studying behavioral patterns (e.g., MAFFEI et al., 2005; Di BitetTi et al., 2006; Monroy-VILChis et al., 2011). Camera-trapping is highly accurate because species may be clearly identified from photos (SRBEKAraujo \& Chiarello, 2005), with the enhanced camera technology over the years facilitating vast improvements in accuracy (SUNARTo et al., 2013). Moreover, different sampling designs have been developed to enhance the use and accuracy of camera traps in rainforest (e.g., SRBEK-ARAUJO \& Chiarello, 2005, 2007, 2013; Kelly, 2008; Tobler et al., 2008; Melo et al., 2012). However, camera-trapping is expensive, especially for short-term studies, and implies a high initial cost investment in field material (SILVEIRA et al., 2003; Lyra-Jorge et al., 2008b). Due to this high initial cost, camera-trapping has not been used in the majority of studies implemented in Brazil.

All non-invasive methods have advantages and disadvantages and should be deployed according to study objectives and target species characteristics. For example, LyRA-Jorge et al. (2008b) and Silveira et al. (2003) recommended camera traps as the best method for sampling mammals. In contrast, BAREA-AzCón et al. (2007) had greater success and efficiency in detecting carnivores in a typical Mediterranean landscape using scent stations and surveys for signs of presence than camera-trapping or live-trapping. Another study carried out in the Pantanal (Brazil) obtained better results for detecting footprints of medium-to-largesized mammals with sand plots than with an artificial method involving two overlapping plastic sheets (Olifiers et al., 2011), but those authors suggested that the latter approach might be more efficient in the long term as animals became familiarized with the artificial structure in their landscape. Ribeiro \& Melo (2013) also recommended sand plots to sample mammals in Central Brazil, describing the method as being cheap and efficient. However, the authors recognized that sand plots are time-consuming, physically demanding and climate-dependent, and do not allow species abundance quantification. Other authors have recommended a large sampling effort combining different methods and statistical analyses (e.g., MunARI et al., 2011), with complementary data from different sources such as photos, spoor and visual sightings enhancing survey efficiency.

Due to this myriad of survey options, assessments of the performance of different sampling methods are needed to improve the efficiency of mammal inventories and surveys (SRbeK-Araújo \& Chiarello, 2005; Gaidet-Drapier et al., 2006; BAREA-Azcón et al., 2007; Olifiers et al., 2011). Thus, the present study focused on assessing the cost and efficiency of three methods often used to register the number of species in a typical Neotropical semi-deciduous seasonal forest. More specifically, our objective was to test the cost-efficiency of three non-invasive sampling methods for medium and large mammals in seasonal tropical forests: camera traps, direct observations and searches for tracks/footprints.

\section{MATERIAL AND METHODS}

Study area. Fieldwork was carried out between July and August 2009 and January and February 2010 in the Serra do Japi Biological Reserve (REBIO Serra do Japi, $23^{\circ} 12^{\prime}-23^{\circ} 21^{\prime} \mathrm{S}$ and $46^{\circ} 30^{\prime}-47^{\circ} 05^{\prime} \mathrm{W}$, Fig. 1) near the city of Jundiaí, state of São Paulo, southeastern Brazil. The REBIO Serra do Japi covers an area of 2,071 hectares and has a strongly seasonal climate, with hot rainy (October to March) and dry cold (April to September) seasons (PINTo, 1992). Land cover is dominated by two major vegetation types: secondary semi-deciduous seasonal forest (VELOSO \& 


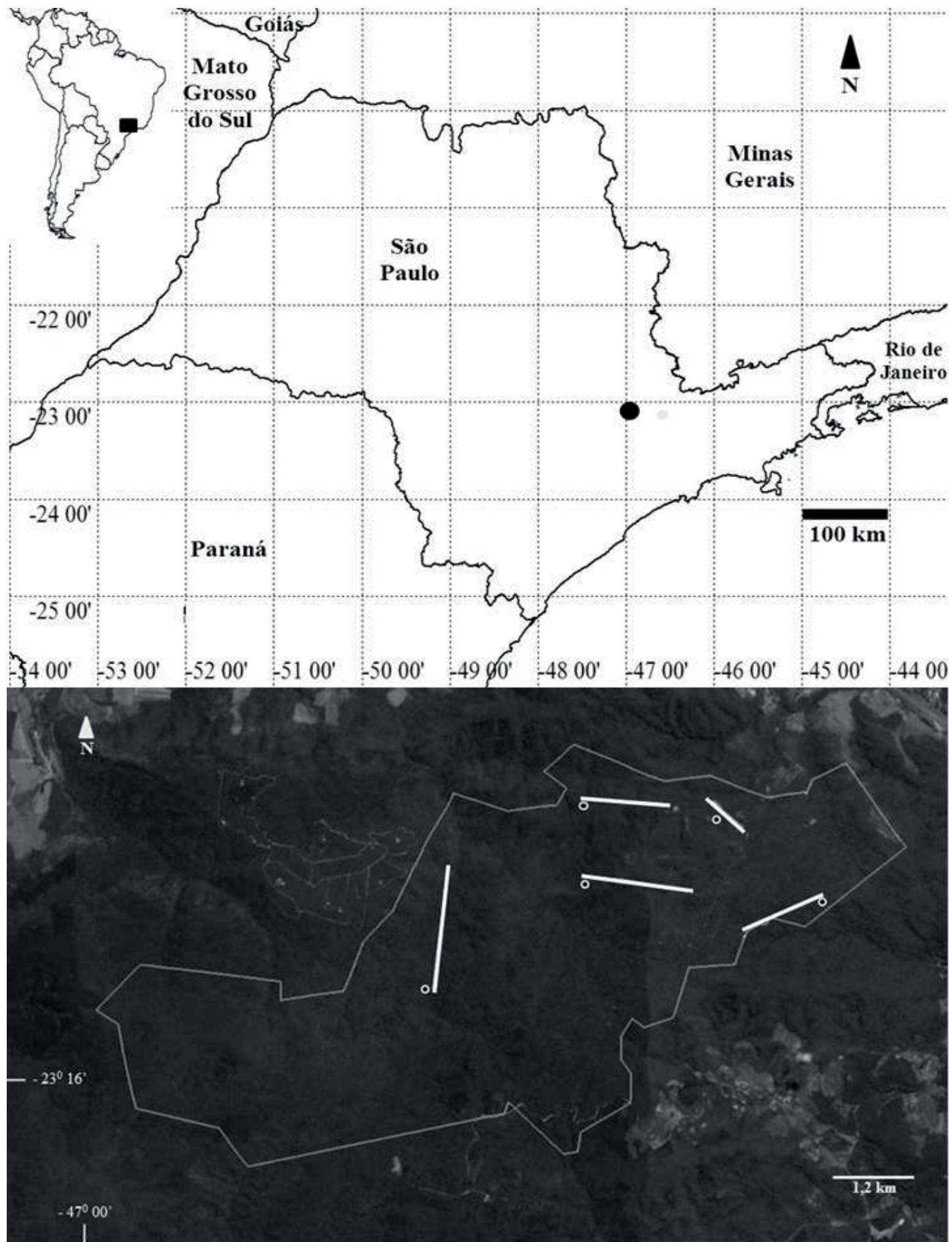

Fig. 1. Serra do Japi Biological Reserve location (São Paulo, Brazil), and camera trap (white circles) and transect placement within the reserve limits. Thin line: limits of REBIO Serra do Japi. Satellite image from Google Earth ${ }^{\circledR}$.

GóEs-FILHO, 1982) and semi-deciduous mesophytic highland forest with sparse rocky outcrops (LEITÃo-FILHO, 1992). However, small patches of mixed forest and Eucalyptus plantations are also present.

Data collection. The REBIO Serra do Japi has a network of trails that spread throughout the area. Of those we selected five trails, averaging $2.53 \pm 1.5 \mathrm{~km}$ long, located between 1,000 and 1,250 $\mathrm{m}$ above sea level, to implement our study, following recommendations for surveying medium- to large-sized mammals (BAREA-AzCón et al., 2007). These 
Tab. I. Medium and large wild mammals detected in Serra do Japi Biological Reserve, Jundiaí, State of São Paulo (Brazil), between July and August 2009 and January and February 2010, and sampling methods used, their sampling effort and efficiency (species richness detected).

\begin{tabular}{|c|c|c|c|}
\hline \multirow{2}{*}{ Species } & \multicolumn{3}{|c|}{ Record Type } \\
\hline & Signs of presence & Direct observations & Camera traps \\
\hline Didelphis aurita Wied-Neuwied, 1826 & $\mathrm{X}$ & - & - \\
\hline Bradypus variegatus Schinz, 1825 & - & $\mathrm{X}$ & - \\
\hline Dasypus novemcinctus Linnaeus, 1758 & $\mathrm{X}$ & - & $X$ \\
\hline Cabassous tatouay (Desmarest, 1804) & $\mathrm{X}$ & $\mathrm{X}$ & - \\
\hline Callithrix aurita (Humboldt, 1812) & - & $\mathrm{X}$ & - \\
\hline Callithrix penicillata (Humboldt, 1912) & - & $X$ & - \\
\hline Callicebus nigrifrons (Spix, 1823) & - & $X$ & - \\
\hline Cerdocyon thous (Linnaeus, 1766) & - & - & $X$ \\
\hline Leopardus pardalis (Linnaeus, 1758) & $\mathrm{X}$ & - & $\mathrm{X}$ \\
\hline Puma concolor (Linnaeus, 1771) & $\mathrm{X}$ & - & $\mathrm{X}$ \\
\hline Procyon cancrivorus (G. [Baron] Curvier, 1798) & $\mathrm{X}$ & $\mathrm{X}$ & $\mathrm{X}$ \\
\hline Nasua nasua (Linnaeus, 1766) & $\mathrm{X}$ & $\mathrm{X}$ & - \\
\hline Conepatus semistriatus (Boddaert, 1785) & $\mathrm{X}$ & $\mathrm{X}$ & - \\
\hline Eira barbara (Linnaeus, 1758) & $\mathrm{X}$ & $\mathrm{X}$ & - \\
\hline Pecari tajacu (Linnaeus, 1758) & $\mathrm{X}$ & $X$ & - \\
\hline Mazama gouazoubira (Fisher, 1814) & $\mathrm{X}$ & $X$ & $\mathrm{X}$ \\
\hline Guerlinguetus ingrami Grey, 1821 & - & $\mathrm{X}$ & - \\
\hline Cuniculus paca Wagler, 1830 & $\mathrm{X}$ & - & - \\
\hline Cavia aperea Pallas, 1766 & - & $\mathrm{X}$ & - \\
\hline Hydrochoeris hydrochaeris Brisson, 1762 & $\mathrm{X}$ & - & - \\
\hline Dasyprocta leporina Linnaeus, 1758 & $\mathrm{X}$ & $X$ & - \\
\hline Sylvilagus brasiliensis (Linnaeus, 1758) & $\mathrm{X}$ & - & $\mathrm{X}$ \\
\hline Species richness & 15 & 14 & 7 \\
\hline Number of sampling days & 40 & 40 & 45 \\
\hline Sampling effort & $350.5 \mathrm{~km}$ & $350.5 \mathrm{~km}$ & 270 camera-days \\
\hline
\end{tabular}

stretches of trails, spaced with a minimum inter-trail distance of $700 \mathrm{~m}$, corresponded to line transects simultaneously monitored for direct observations, signs of presence and camera trap surveillance (Fig. 1, Tab. I). Overall, we set five camera traps, one per line transect. Each camera trap, located near the beginning of each line transect, was fixed at 30 to $40 \mathrm{~cm}$ above the ground on a trunk, pointing across the trail (SRbeK-AraúJo \& Chiarello, 2005). We programmed the cameras to record photos with a 60 seconds inter-photo delay, i.e. the maximum time period allowed by the device. During each fieldwork session, cameras were activated on the first day, remained active for the following five consecutive days, were removed to change films and batteries on the sixth day and were then reactivated on the same day. Cameras were active for 22 days for the first fieldwork session (July and August 2009) and 23 days for the second session (January and February 2010).

Line transects were walked by two field technicians in the morning $(07: 00 \mathrm{~h})$ and again in the afternoon $(16: 00 \mathrm{~h})$, at an average speed of $2.7 \mathrm{~km} / \mathrm{h}$. Each transect was monitored for six consecutive days for three weeks. In the fourth week transects were sampled for only two days, totaling 20 sampling days for each fieldwork session (July and August 2009 and January and February 2010). Whenever an animal was observed, we recorded the time (hour and minutes), site and number of individuals identified, following BUCKLAND et al. (1993).
Simultaneously to direct observations, we also recorded all signs of presence (e.g., footprints) of mediumand large-sized mammals along each line transect. Signs of presence were only used to determine species presence/ absence for each transect per inventory. Footprint identification was based on field guide descriptions (BECKER \& DALPONTE, 1991; Oliveira \& Cassaro, 2005).

Data analysis. Camera trap sampling effort was assessed as follows: number of camera-traps $\mathrm{x}$ number of sampling days $(1 \mathrm{~d}=24 \mathrm{~h})$ (SRbeK-AraúJo \& Chiarello, 2005). For direct observations and signs of presence, sampling effort was measured in $\mathrm{km}$, considering the total kilometers walked in transects. Sampling success was also analyzed using species accumulation curves (CoLWELL et al., 2012) for each method. We considered 45 as the maximum number of sampling days, defined according to the method that had the highest number of sampling days, i.e. camera traps (Tab. I). Estimates 9.1 software was used to produce extrapolations of species accumulation curves (COLWELL et al., 2012). We first tested data normality and homogeneousness of variances using the Shapiro-Wilk's test and the Levene's test, respectively. None of the variables presented significant deviation from a normal distribution $(\mathrm{p}>0.05)$ or presented heterogeneity of variance ( $p>0.05)$, so we used Analysis of Variance (One way ANOVA; Past 2.16 software; HAMMER et al., 2001) to compare richness between sampling methods (e.g., Ribeiro \& Melo, 2013), with a post hoc Tukey test 
(HSD), considering each track and each camera trap as a repeated measure. We excluded from all analyses the two domestic species registered: Canis familiaris Linnaeus, 1758 and Felis catus Linnaeus, 1758. All footprints of Mazama spp. were considered as belonging to Mazama gouazoubira Fischer, 1814 as this was the only species identified in camera trap photos.

We tested the cost-efficiency of the three non-invasive sampling methods by quantifying the expenses associated with each, following LYRA-JORGE et al. (2008b), and relating them with the number of species detected. Expenses were divided into fixed and variable costs. Fixed expenses were those that did not vary throughout the project and were associated with the field methods tested, including temporary equipment for field data collection (GPS, notebook, data storage, etc.) and the cost of a vehicle and its depreciation. During fieldwork, technicians stayed at a field station within REBIO, so there was no transportation cost associated with getting to the field site. As these costs were similar for all methods, we focused our analysis on the variable expenses.

Variable expenses were those specific for each method. Thus, for camera trapping we considered the cost of camera traps and accessories (five batteries per camera trap, film and film development) and daily expenses for a researcher and a field assistant. Daily expenses were calculated for a nineday period, to allow for checking each camera at five-day intervals, as described previously. For methods involving signs of presence and direct observations, we only considered daily expenses for a researcher and a field assistant, as well as the costs of acquiring field guides. For each of these methods, fieldwork was implemented by two individuals (researcher and field assistant), since this enhanced the ability to identify animals by direct observations, increased the accuracy of identifying footprints or other signs of presence and improved fieldwork safety (in case of accident, e.g., a fall, snake or arthropod bite). We considered the daily costs (DC) of each method as follows:

$$
D C=\frac{\text { total cost }}{\text { Number of sampling days }}
$$

For each method, the cost of recording each species (i.e., Species Record Cost - SRC) was obtained as follows:

$$
S R C=\left(\frac{\text { total cost }}{\begin{array}{c}
\text { minimum number of days } \\
\text { needed to sample } \\
\text { all species detected }
\end{array}} /\right. \text { species richness }
$$

Costs are presented in local currency ("Brazilian Real" - R\$) and American Dollar (US\$) (average exchange rate in 2010, the year of study: US\$1.00 R R1.80).

\section{RESULTS}

The total species richness recorded for our study area was 24 species, including two domestic species $-C$. familiaris and F. catus (Tab. I). The method that recorded the largest number of species was that based on signs of presence detection $(n=15)$, followed by direct observations $(n=14)$ and camera traps $(n=7)$, which was the least efficient method. However, the species' accumulation curves stabilized for signs of presence detection and camera trapping, indicating the need for greater sampling effort for direct observations (Fig. 2).

The ANOVA showed that there were significant differences in species richness estimates between sampling methods $(F=5.86 ; p=0.01)$. Post hoc Tukey tests revealed that there were significant differences only between the data from camera traps and that from signs of presence (HSD $=4.54 ; \mathrm{p}=0.01)$, and between camera traps and direct observations $(\mathrm{HSD}=3.73 ; \mathrm{p}=0.05)$. There was no difference between signs of presence and direct observations (HSD = $0.81 ; \mathrm{p}=0.83)$.

Cost-efficiency analysis revealed that the daily costs of variable expenses, estimated for both signs of presence and direct observations, were U\$ 123.33 (R\$ 222.00), for the 40 days of sampling. Signs of presence presented a cost of U\$ 10.27 (R\$ 18.50) to record each species and U\$ 8.80 (R\$ 15.85) for direct observations. Camera trap expenses were slightly lower at U\$ $71.13(\mathrm{R} \$ 128.04)$ per day and the cost to record each species was U\$ 10.16 (R\$ 18.29) for 45 days of sampling (Tab. II).

\section{DISCUSSION}

The methods that clearly detected more mediumto-large-sized mammal species were those based on signs of presence and direct observations. Camera trapping exhibited poor performance in sampling our focal species, although it detected one species (Cerdocyon thous Linnaeus, 1766) not registered by the other two methods. Detection of signs of presence recorded species more quickly than the other two methods, achieving high species richness in a shorter time period (see species accumulation curves, Fig. 2). The total number of species detected by the three

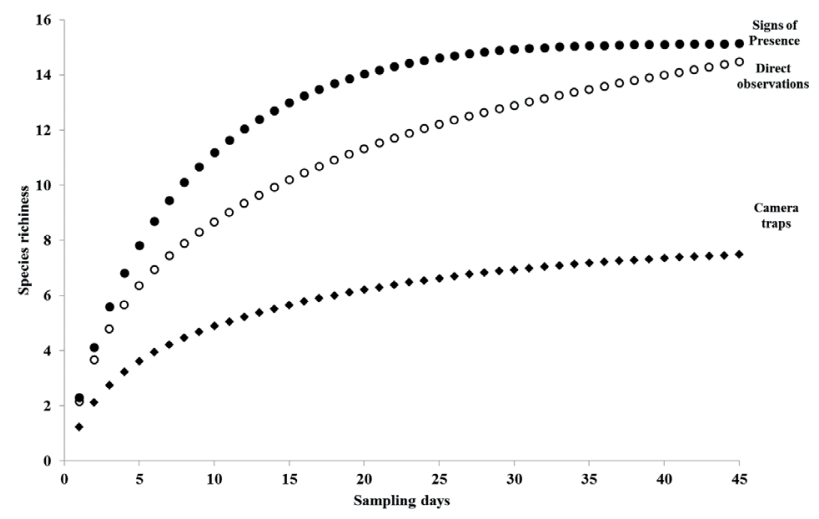

Fig. 2. Species accumulation curves for 45 sampling days for each method used to sample mammals in Serra do Japi Biological Reserve, Jundiaí, State of São Paulo, Brazil in July and August 2009 and January and February 2010. 
Tab. II. Estimated costs of the variable expenses associated with each method [signs of presence (SP), direct observations (DO) and camera traps] used to survey non-volant mammals. Average exchange rate of 2010 (at time of study): US\$1.00 R $\$ 1.80$.

\begin{tabular}{|c|c|c|c|c|}
\hline Method & Item & Unit Value- R\$ (US\$) & Quantity & Total- R\$ (US\$) \\
\hline \multirow[t]{3}{*}{ Signs of presence and Direct observations } & Per-diem for researcher & $150.00(83.33)$ & 40 & $6,000.00(3,333.33)$ \\
\hline & Per-diem for field assistant & $70.00(38.88)$ & 40 & $2,800.00(1,555.55)$ \\
\hline & Field guides & & 2 & $80.00(44.44)$ \\
\hline Total & & & & $8,880.00(4,933.33)$ \\
\hline Total of sampling days & & & & 40 \\
\hline Day last species added (SP) & & & & 32 \\
\hline Day last species added (DO) & & & & 40 \\
\hline Per-day cost (SP and DO) & & & & $222.00(123.33)$ \\
\hline Per-species cost (SP) & & & & $18.50(10.27)$ \\
\hline Per-species cost (DO) & & & & $15.85(8.80)$ \\
\hline \multirow[t]{6}{*}{ Camera traps } & Camera trap & $400.00(222.22)$ & 5 & $2,400.00(1,333.33)$ \\
\hline & Films (24 poses) & $3.95(2.19)$ & 56 & $221.20(122.88)$ \\
\hline & Batteries (pair) & $9.70(5.38)$ & 80 & $776.00(431.11)$ \\
\hline & $\begin{array}{l}\text { Film development (film of } 24 \\
\text { exposures) }\end{array}$ & $7.00(3.88)$ & 56 & $392.00(705.60)$ \\
\hline & Per-diem for researcher & $150.00(83.33)$ & 9 (checks of cameras) & $1,350.00(750.00)$ \\
\hline & Per-diem for field assistant & $70.00(38.88)$ & 9 (checks of cameras) & $630.00(350.00)$ \\
\hline Total & & & & $5,762.20(3,205.11)$ \\
\hline Total of sampling days & & & & 45 \\
\hline Day last species added & & & & 45 \\
\hline Per-day cost & & & & $128.04(71.13)$ \\
\hline Per-species cost & & & & $18.29(10.16)$ \\
\hline
\end{tabular}

methods combined represents approximately $56.41 \%$ of those occurring in REBIO Serra do Japi (CARVALHO et al., 2013), and approximately $31.88 \%$ of the medium- and large-sized mammals that occur in São Paulo state (VIVo et al., 2011). Moreover, using only signs of presence, we detected ca. $38.46 \%$ of the medium-to-large-sized wild mammals that inhabit the REBIO Serra do Japi (CARVALHO et al., 2013). This low detection rate might indicate that greater sampling effort is needed to ensure that better species detection is achieved.

The species accumulation curve increased more rapidly for the signs of presence method, indicating that it is a more efficient approach in Neotropical semi-deciduous or mesophytic forest. Implementation of this method resulted in a higher number of records, representing twice the number of records as camera traps. RiBEIRo \& MeLo (2013) also reported that sand plots and censuses along transects reached a given number of species more rapidly than camera traps, indicating that camera traps sampled species more gradually. We could improve the species detection rate by camera trapping if we increased the number of cameras within the study area. Usually, the period needed to efficiently survey an area for species inventory studies is inversely proportional to the number of camera traps used (ROVERO et al., 2013). Moreover, a larger number of camera traps allows modification of their spatial distribution, thereby improving sampling efficiency (Melo et al., 2012; SRBEKAraujo \& Chiarello, 2013) and allowing lower-density and cryptic species to be recorded (Melo et al., 2012). For example, using different varying camera trap positions (e.g., monitoring both natural and artificial trails and setting cameras at potential animal shelters), can increase sampling efficiency and improve the chances of recording different mammalian species (Melo et al., 2012). When only a limited number of cameras are available, Si et al. (2014) showed that it is more efficient for species richness studies to constantly relocate cameras to new sites rather than sampling the same sites over a longer period.

The low richness recorded by camera traps may have been influenced by two factors. Firstly, the devices we used had been intensively used in the field in the past, which may have decreased their trigger accuracy/sensitivity. In addition, the cameras were analogic, which may be a disadvantage as digital cameras have more sensitive sensors for capturing images of mammals, including small mammals (see AMORIM \& Andriolo, 2001; Delciellos et al., 2012). Moreover, modern digital cameras can store more photos, allow instant viewing, provide more extensive image metadata, can shoot videos, and have a wider availability of infrared flash options (Sunarto et al., 2013). Secondly, camera trapping is sitelimited, sampling a small area confined to the focal range of the camera. In contrast, detection of signs of presence and direct observations sample the entire track and not just a particular location which may increase the probability of detecting an individual. However, the continuous sampling of camera traps (i.e., cameras are continuously active for long durations) may counterbalance this limitation, as line transect sampling is time-restricted and depends on the sampling frequency. In our study, it seems that the more extensive sampling period of the camera traps could not compensate for their spatial restrictiveness. 
Other authors have also detected a similar pattern. For example, in an Atlantic Forest area of Brazil, LYRA-JORGE et al. (2008b) compared the efficiency of mammal detection of analogic camera traps with track plots, and observed differences in the number of records; track plots had a higher number of records than camera traps and for this reason these authors recommended it for use in time limited surveys, with limited budgets. However, in other studies, EsPARTOSA et al. (2011) and Ribeiro \& Melo (2013) did not detect differences between analogic camera traps and sand plots (in a Brazilian Atlantic Forest) or direct observations (in the Brazilian Savannah, Cerrado), respectively. EsPARTOSA et al. (2011) hypothesized that this lack of differences in their study may be linked to the number and spatial distribution of sand plots, which covered a larger area than did the camera traps.

Direct observations are more frequently used in the Neotropics to monitor primates and arboreal species (Peres, 1999), which rarely descend from the treetops or move along trails, as was corroborated by our results. The primates recorded by direct observations in our study were not detected by either of the other two methods used that only recorded terrestrial species that move long distances and have nocturnal and elusive habits [e.g., ocelot-Leopardus pardalis (Linnaeus, 1758)], or that occur in low density (e.g., deer - Mazama spp.) (Tomas \& MirandA, 2003).

Although its efficiency for species detection was lower, camera traps were the most accurate in terms of species identification, since the photo allowed easier and more precise identification. For species with individual variation in pelage pattern [e.g., tigers Panthera tigris (Linnaeus, 1758)] or when individuals present unique marks (e.g., scars) (O'ConNell et al., 2011), it is sometimes even possible to identify individuals based on a photo, whereas with other methods this discrimination is often difficult or even impossible (with the exception of molecular ecology methods; LoNG et al., 2008). Camera traps also present some logistic advantages, since only one or two trained technicians (not necessarily highly-specialized) are needed to maintain the cameras (LYRA-JoRgE et al., 2008b). Direct observations and searching for tracks/footprints requires highly-experienced and specialized technicians for correct visual identification of animals and their signs of presence in the field (as was the case for our study). This is especially true in areas of sympatry for congeneric species, when discrimination between the spoor of similar species is often very difficult. For example, ANGELI et al. (2014) investigated footprint morphometrics of Mazama species and concluded that it was very difficult to discriminate these species of deer (with the exception of the Amazonian species) when footprints have been formed under similar conditions. Other authors have asserted that the footprints of small wildcats cannot be discriminated, with the exception of $L$. pardalis whose larger footprint allows it to be readily identified (BECKER \& DALPONTE, 1991; CARVAlHo et al., 2015).

In terms of the initial investment in equipment, camera traps represent the most expensive method (LYRA-JORGE et al., 2008b). However, the best methods to study mammals are those that show greater accuracy, better capture success and maximal probability of correct identification of the specimen. Camera trapping encompasses these three traits, although it is commonly accepted that it is a more expensive approach (STANDER, 1998; SADLIER et al., 2004; GAIDETDrAPIER et al., 2006; BAREA-AzEÓN et al., 2007; LyRAJORGE et al., 2008b). Our data shows that camera traps have a lower cost per day than the other two methods (i.e., signs of presence and direct observations) and a similar cost to record each species, despite camera-traps having detected the lowest number of species. Signs of presence and direct observations had a higher daily cost because researchers and field assistants needed to undertake fieldwork every day, while for camera traps they only needed to be in the field to change batteries or data storage cards every five days. In terms of cost-benefit, signs of presence and direct observations are a better methodology than camera trapping because they record more species, despite the higher costs during sampling and similar cost to record each species. Our results are similar to those described by LYRA-JORGE et al. (2008b), which reported camera trapping has having a better cost-benefit ratio and lower per-day cost than other methods, especially for large spatial and temporal surveys.

Different sampling or monitoring methods may be required depending on the study objective and/or mammal species targeted. Our study seems to indicate that for mammalian inventories in Brazilian Atlantic Forest (especially in secondary semi-deciduous forests), direct observations and searches for signs of presence (or track plots, which were not tested in our study, but have been recommended by other authors, e.g., LYRA-JORGE et al., 2008b) are more efficient methods. These methods are cheap and easy to apply, but require a higher level of expertise. Direct observations are particularly suitable for collecting data on primate and arboreal species in our study region. Complementary use of both direct observations and signs of presence improves species detection. For long-term studies, camera traps may be an important approach when used in conjunction with the other two methods studied here, as they enhance identification accuracy, may allow individual identification, and permit more accurate abundance estimates. However, we strongly advise the use of state-of-the-art cameras to avoid problems associated with older models and to enhance the quality and quantity of the data acquired.

Acknowledgements. We thank Serra do Japi REBIO for the collection permit and the support during fieldwork, as well as the Centro Brasileiro para a Conservação da Felinos Neotropicais. We thank the field assistants R. M. Dias and M. S. M. Godoy. We thank the Jundiaí City Hall, the Municipal Secretary for Planning and Environment, Municipal Environmental Guard of Jundiaí, Tetra Pak® of Brazil, CCR AutoBAn (autopista Anhanguera-Bandeirantes) and Vetnil ${ }^{\circledR}$ for providing us with part of the field material. We thank J.M. Barbanti Duarte for the identification of deer specimens through photos, and D. Dias, H. G. Bergallo, A. Pires, A. F. B. Araújo and L. Geise for their invaluable suggestions on this manuscript. W. D. Carvalho received a M.Sc. scholarship from CAPES. C. E. L. Esbérard received a research fellowship from $\mathrm{CNPq}$ and a FAPERJ fellowship as a "Jovem Cientista do Nosso Estado 2008-2014". L. M. Rosalino was funded by postdoctoral fellowships from Fundação para a Ciência e a Tecnologia (FCT) and Fundo Social Europeu (III Quadro Comunitário de 
Apoio) (SFRH/BPD/35842/2007; SFRH/BPD/101556/2014). The present study was carried out under a temporary permit by SISBIO (no. 19.644-1 / proc. 3.829.564) and a permit by IBAMA (no. 10356-1, 2007/09/06). We would like to thank the finacial support of University of Aveiro (Department of Biology), CESAM (UID/AMB/50017), FCT/MEC through national funds and the co-funding by the FEDER, within the PT2020 Partnership Agreement and Compete 2020. The final version of the manuscript was reviewed by John O'Brien.

\section{REFERENCES}

Alves, L. C. P. S. \& Andriolo, A. 2005. Camera traps used on the mastofaunal survey of Araras Biological Reserve, IEF-RJ. Revista Brasileira de Zoociências 7(2):231-246.

AMORIM, T. O. S. \& ANDRIOLO, A. 2011. Variáveis ambientais e ocorrência de marsupiais didelfídeos em um fragmento de Mata Atlântica, no município de Juiz de Fora, MG: uma amostragem por armadilhas fotográficas. Revista Brasileira de Zoociências 13(1- 3):87-101.

Angeli, T.; Oliveira, M. L. \& Duarte, J. M. B. 2014. Differentiation of deer species of the genus Mazama by track morphometry. Studies Neotropical Fauna Environment 49(3):199-203.

Barea-Azcón, J. M.; Virgós, E.; Ballesteros-Duperón, E.; Moleón, M. \& Chirosa, M. 2007. Surveying carnivores at large spatial scales: a comparison of four broad-applied methods. Biodiversity and Conservation 16(4): 1213-1230.

BeCKer, M. \& DALPONTE, J. C. 1991. Rastros de mamíferos silvestres brasileiros: um guia de campo. Brasília, Universidade de Brasília. 180 p.

Buckland, S. T.; ANDerson, D. R.; Burnham, K. P. \& LaAke, J. L. 1993. Distance sampling: estimating abundance of biological populations. London, Chapman and Hall. 446p.

Carvalho, W. D.; Godoy, M. S. M.; Adania, C. H. \& Esbérard C. E. L. 2013. Assembléia de mamíferos não voadores da Reserva Biológica Serra do Japi, Jundiaí, São Paulo, sudeste do Brasil. Bioscience Journal 29(5):1370-1387.

Carvalho, W. D.; Rosalino, L. M.; Dalponte, J. C.; Santos, B.; Adania, C. H. \& EsBÉRARD, C. E. L. 2015. Can footprints of small and medium sized felids be distinguished in the field? Evidences from Brazil's Atlantic Forest. Tropical Conservation Science 8(3):760-777.

CHAME, M. 2003. Terrestrial mammal feces: a morphometric summary and description. Memórias do Instituto Oswaldo Cruz 98(Suppl. 1):71-94.

Colwell, R. K.; ChaO, A.; Gotelli, N. J.; Lin, S-Y.; Mao, C.X.; Chazdon, R. L. \& LongINO, J. T. 2012. Models and estimators linking individualbased and sample-based rarefaction, extrapolation, and comparison of assemblages. Journal of Plant Ecology 5(1):3-21.

Delciellos, A. C.; Novaes, R. L. M.; Loguercio, M. F. C.; Geise, L.; Santori, R. T.; Souza, R. F.; Papi, B. S.; Raíces, D.; Vieira, N. R.; Felix, S.; Detogne, N.; Silva, C. C. S.; Bergallo, H. G. \& RochaBarbosa, O. 2012. Mammals of Serra da Bocaina National Park, state of Rio de Janeiro, southeastern Brazil. Check List 8(4):675-692.

Di Bitetti, M. S.; Paviolo, A. \& De Angelo, C. 2006. Density, habitat use and activity patterns of ocelots (Leopardus pardalis) in the Atlantic Forest of Misiones, Argentina. Journal of Zoology 270(1):153-163.

EISENBERG, J. F. \& THORINGTON JR., R. W. 1973. A preliminary analysis of a neotropical mammal fauna. Biotropica 5(3):150-161.

Emmons, L. H.; Sherman, P.; Bolster, D.; Goldizen, A. \& Terborgh, J. 1989. Ocelot behavior in moonlight. In: EISENBERG, J. F. ed. Advances in Neotropical Mammalogy. Gainesville, Sandhill Crane Press, p. 233-240.

Espartosa, K. D.; Pinotti, B. T. \& PARdini, R. 2011. Performance of camera trapping and track counts for surveying large mammals in rainforest remnants. Biodiversity and Conservation 20(12):2815-2829.

Gaidet-Drapier, N.; Fritz, H.; Bougarel, M.; Renaud, P. C.; Poilecot, P.; Chardonnet, P.; Goid, G.; Poulet, D. \& Bel, S. L. 2006. Cost and efficiency of large mammal census techniques: comparison of methods for a participatory approach in a communal area, Zimbabwe. Biodiversity and Conservation 15(2):735-754.

Hammer, O.; Harper, D. A. T. \& Ryan, P. D. 2001. Past: Paleontological statistics software package for education and data analysis. Palaeontologia Electronica 4(1):1-9.
KelLy, M. J. 2008. Design, evaluate, refine: camera trap studies for elusive species. Animal Conservation (Commentary) 11(3):182-184.

LeItÃo-Filho, H. F. 1992. A flora arbórea da Serra do Japi. In: Morellato, L. P. C. ed. História natural da Serra do Japi: ecologia e preservacão de uma área florestal no sudeste do Brasil. Campinas, Editora da UNICAMP, p. 40-62.

Long, R. A.; MacKay, P.; ZielinsKi, W. J. \& RaY, J. C. 2008. Noninvasive survey methods for carnivores. Washington DC, Island Press. 400p.

Lyra-Jorge, M. C.; Ciocheti, G. \& Pivello, V. R. 2008a. Carnivore mammals in a fragmented landscape in northeast of São Paulo State, Brazil. Biodiversity and Conservation 17(7):1573-1580.

Lyra-Jorge, M. C.; Ciocheti, G.; Pivello, V. R. \& Meirelles, S. T. 2008b. Comparing methods for sampling large- and medium-sized mammals: camera traps and track plots. European Journal of Wildlife Research 54(4):739-744.

Maffei, L.; Noss, A. J.; Cú́llar, E. \& Rumiz, D. I. 2005. Ocelot (Felis pardalis) population densities, activity, and ranging behaviour in the dry forest of eastern Bolivia: data from camera trapping. Journal of Tropical Ecology 21(3):349-353.

Maffei, L.; Noss, A. J.; Silver, S. C. \& Kelly, M. J. 2011. Abundance density case study: Jaguars in the Americas. In: O'ConNell, A. F.; Nichols, J. D. \& Karanth K. U. eds. Camera Traps in Animal Ecology. New York, Springer, p. 119-144.

Melo, G. L.; Sponchiado, J. \& CÁCeres, N. C. 2012. Use of camera-traps in natural trails and shelters for the mammalian survey in the Atlantic Forest. Iheringia, Série Zoologia 102(1):88-94.

Monterroso, P.; Castro, D.; Silva, T. L.; Ferreras, P.; Godinho, R. \& ALvES, P. C. 2012. Factors affecting the (in)accuracy of mammalian mesocarnivore scat identification in South-western Europe. Journal of Zoology 289(4):243-250.

Monroy-Vilchis, O.; Zarco-GonZÁlez, M. M.; RodríGuez-Soto, C.; SORIA-DíAz, L. \& Urios, V. 2011. Fototrampeo de mamíferos em la Sierra Nanchititla, México: abundancia relativa y patrón de actividad. Revista Biologia Tropical 59(1):373-383.

Munari, D. P.; Keller, C. \& Venticinque, E. M. 2011. An evaluation of field techniques for monitoring terrestrial mammal populations in Amazonia. Mammalian Biology 76(4):401-408.

Negrão, M. F. F. \& Valadares-Pádua, C. 2006. Registros de mamíferos de maior porte na Reserva Florestal do Morro Grande, São Paulo. Biota Neotropical 6(2):1-13.

O’Connell, A. F.; Nichols, J. D. \& Karanth, K. U. 2011. Camera traps in animal ecology. Methods and analyses. New York, Springer. 271p.

Olifiers, N.; Loretto, D.; Rademaker, V. \& Cerqueira, R. 2011. Comparing the effectiveness of tracking methods for medium to largesized mammals of Pantanal. Zoologia 28(2):207-213.

Oliveira, T. G. \& Cassaro, K. 2005. Guia de campo dos felinos do Brasil. São Paulo, Instituto Pró Carnívoros, Sociedade de Zoológicos do Brasil, Fundação Parque Zoológico de São Paulo. 80p.

Peres, C. A. 1999. General guidelines for standardizing line transect surveys of tropical forest primates. Neotropical Primates 7:11-16.

Pinto, H. S. 1992. Clima da Serra do Japi. In: Morellato, L. P. C. ed. História natural da Serra do Japi: ecologia e preservação de uma área florestal no sudeste do Brasil. Campinas, Editora da UNICAMP, p. 30-38.

Ribeiro, P. \& Melo, F. R. 2013. Mamíferos de médio e grande porte de uma área agricultável em Terezópolis (GO) com notas sobre métodos de amostragem. Neotropical Biological Conservation 8(2):68-78.

Rovero, F.; Zimmermann, F.; BerZi, D. \& MeeK, P. 2013. "Which camera trap type and how many do I need?" A review of camera features and study designs for a range of wildlife research applications. Hystrix, the Italian Journal of Mammalogy 24:148-156.

Rudran, R.; Kunz, T. H.; Southwell, C.; Jarman, P. \& Smith, A. P. 1996. Observational techniques for nonvolant mammals. In: WILSON, D. E.; Cole, F. R.; Nichols, J. D.; Rudran, R. \& Foster, M. S. eds. Measuring and monitoring biological diversity. Standard methods for mammals. Washington DC, Smithsonian Institution Press, p. 81-103.

Sadlier, L. M. J.; Webbon, C. C.; Backer, P. J. \& Harris S. 2004. Methods of monitoring red foxes Vulpes vulpes and badgers Meles meles: are field signs the answer? Mammal Review 34(1-2):75-98. 
Scoss, L. M.; Júnior, P. M.; Silva, E. \& Martins S. V. 2004. Uso de parcelas de areia para o monitoramento de impacto de estradas sobre a riqueza de espécies de mamíferos. Revista Árvore 28(1):121-127.

Si, X.; KAYS, R. \& Ding, P. 2014. How long is enough to detect terrestrial animals? Estimating the minimum trapping effort on camera traps. PeerJ. 2: e374.

Silveira, L.; Jácomo, A. T. \& Diniz-Filho, J. A. 2003. Camera trap, line transect census and track surveys: a comparative evaluation. Biological Conservation 114(3):351-355.

Srbek-Araújo, A. C. \& Chiarello, A. G. 2005. Is camera-trapping an efficient method to surveying mammals in neotropical forest? Journal Tropical Ecology 21(1):121-125.

2007. Armadilhas fotográficas na amostragem de mamíferos: considerações metodológicas e comparação de equipamentos. Revista Brasileira de Zoologia 24(3):647-656.

.2013. Influence of camera-trap sampling design on mammal species capture rates and community structures in southeastern Brazil. Biota Neotropical 13(2):51-62.

STANDER, P. E. 1998. Spoor counts as indices of large carnivore populations: the relationship between spoor frequency, sampling effort and true density. Journal of Applied Ecology 35(3):378-385.
Sunarto; Sollmann, R.; Mohamed, A. \& Kelly, M. J. 2013. Camera trapping for the study and conservation of tropical carnivores. The Raffles Bulletin of Zoology 28:21-42.

Tobler, M. W.; Carrilo-Percastegui, S. E.; Pitman, R. L.; Mares, R. \& Powell, G. 2008. An evaluation of camera traps for inventorying large-and-medium sized terrestrial rainforest mammals. Animal Conservation 11(3): 169-178.

Tomas, W. M. \& Miranda, G. H. B. 2003. Uso de armadilhas fotográficas em levantamentos populacionais. In: CULlen JR., L.; RUDRAN, R. \& Valladares-Pádua, C. eds. Métodos de estudos em biologia da conservação e manejo da vida Silvestre. Curitiba, Editora Universidade Federal do Paraná, p. 243-267.

Veloso, H. P. \& Góes-Filho, L. 1982. 'Fitogeografia brasileira: uma classificação fisionômica-ecológica da vegetação neotropical'. Rio de Janeiro, Boletim Técnico, Projeto Radam Brasil. 85p.

Vivo, M.; Carmignotto, A. P.; Gregorin, R.; Hingst-Zaher, E.; IaCKXimenes, G. E.; Miretzki, M.; Percequillo, A. P.; Junior, M. M. R.; Rossi, R. V. \& TAdDeI, V. A. 2011. Checklist dos mamíferos do Estado de São Paulo, Brasil. Biota Neotropical 11(Supl. 1):111-131. 